\title{
Nonlinear Pulse-Time Conversion in Radioisotope Devices: Analysis and Application Possibilities
}

\author{
A.M. Vodovozov \\ Vologda State University, \\ Lenin str, 15, Vologda 160000, Russia
}

Received 09.03.2021

Accepted for publication 18.05.2021

\begin{abstract}
The paper considers the operation of radioisotope measuring devices under dynamic conditions, when the Poisson pulse flux at the output of the radiation detector becomes unsteady and the nonlinearity of the calibration curve of the device, the stochasticity of the radiation signal and the inertia of the meter significantly complicate the task of estimating the measured physical parameter. of the device and analysis of the possibility of its application for linearization of the characteristics of the device, increasing the speed of the devices and solving the measuring problem in real time.

The process of nonlinear transformation of the radiation signal in the system is analyzed on the basis of the assumption about the exponential distribution of the intervals between the pulses of the information flow at the output of the radiation detector. A generalized algorithm for the synthesis of a given transformation function of a time-pulse computing device of a radioisotope device has been developed according to its mathematical description. To describe the transformation function given by a set of points, it is proposed to use its approximation by a power series.

The proposed calculation formulas are verified by modeling in the Scilab program on a specific example of linearization of the curve of a radioisotope altimeter with a given tabular calibration characteristic. The results obtained confirm the expediency of using time-pulse computing devices for linearizing the conversion curve of radioisotope devices in real time.

Carrying out calculations according to the proposed algorithms by means of modern microelectronics opens up new possibilities for expanding the field of application of radioisotope devices in dynamic problems of industrial flaw detection, measuring the parameters of object movement, thickness of rolled products and coatings, in devices for continuous monitoring of liquid media.
\end{abstract}

Keywords: radioisotope device, nonlinearity, linearization, exponential distribution, time-pulse conversion.

DOI: $10.21122 / 2220-9506-2021-12-2-133-138$

\begin{tabular}{ll}
\hline Адрес для переписки: & Address for correspondence: \\
Водовозов А.М. & Vodovozov A.M. \\
Вологодский государственный университет, & Vologda State University, \\
ул. Ленина, 15, г. Вологда 160000, Россия & Lenin str, 15, Vologda 160000, Russia \\
e-таil: aт.vodovоzоv@gmail.com & e-mail: am.vodovozov@gmail.com \\
\hline Для цитирования: & For citation: \\
A.M. Vодоvоzоv. & A.M. Vodovozov. \\
Nonlinear Pulse-Time Conversion in Radioisotope Devices: & Nonlinear Pulse-Time Conversion in Radioisotope Devices: \\
Analysis and Application Possibilities. & Analysis and Application Possibilities. \\
Приборы и методы измерений. & Devices and Methods of Measurements. \\
2021. - Т. 12, № 2.- С. 133-138. & 2021, vol. 12, no. 2, pp. 133-138. \\
DОI: $10.21122 / 2220-9506-2021-12-2-133-138$ & DOI: 10.21122/2220-9506-2021-12-2-133-138
\end{tabular}




\title{
Нелинейное времяимпульсное преобразование в радиоизотопных приборах: анализ и возможности применения
}

\author{
А.М. Водовозов \\ Вологодский государственньй университет, \\ ул. Ленина, 15, г. Вологда 160000, Россия \\ Поступила 09.03.2021 \\ Принята к печати 18.05.2021
}

Рассмотрена работа радиоизотопных измерительных приборов в динамических условиях, когда пуассоновский поток импульсов на выходе детектора излучения становится нестационарным, а нелинейность градуировочной характеристики прибора, стохастичность радиационного сигнала и инерционность измерителя существенно усложняют задачу оценки измеряемого физического параметра. Целью работы являлась разработка алгоритмов нелинейного времяимпульсного преобразования пуассоновского процесса в структуре радиоизотопного прибора и анализ возможности его применения для линеаризации характеристики прибора, повышения быстродействия приборов и решения измерительной задачи в режиме реального времени.

Проанализирован процесс нелинейного преобразования радиационного сигнала в системе на основе предположения об экспоненциальном распределении интервалов между импульсами информационного потока на выходе детектора излучения. Разработан обобщённый алгоритм синтеза заданной функции преобразования времяимпульсного вычислительного устройства радиоизотопного прибора по её математическому описанию. Для описания функции преобразования, заданной множеством точек, предлагается использовать её аппроксимацию степенным рядом.

Предложенные расчётные формулы проверены моделированием в программе Scilab на конкретном примере линеаризации характеристики радиоизотопного высотомера с заданной таблично градуировочной характеристикой. Полученные результаты подтверждают целесообразность использования времяимпульсных вычислительных устройств для линеаризации характеристики преобразования радиоизотопных приборов в режиме реального времени.

Проведение вычислений по предложенным алгоритмам средствами современной микроэлектроники открывает новые возможности для расширения области применения радиоизотопных приборов в динамических задачах промышленной дефектоскопии, измерения параметров движения объектов, толщины проката и покрытий, в устройствах непрерывного контроля жидких сред.

Ключевые слова: радиоизотопный прибор, нелинейность, линеаризация, экспоненциальное распределение, времяимпульсное преобразование.

DOI: $10.21122 / 2220-9506-2021-12-2-133-138$

\begin{tabular}{|c|c|}
\hline $\begin{array}{l}\text { Адрес для переписки: } \\
\text { Водовозов А.М. } \\
\text { Вологодский государственный университет, } \\
\text { ул. Ленина, 15, г. Вологда 160000, Россия } \\
\text { e-mail: am.vodovozov@gmail.com }\end{array}$ & $\begin{array}{l}\text { Address for correspondence: } \\
\text { Vodovozov A.M. } \\
\text { Vologda State University, } \\
\text { Lenin str, 15, Vologda 160000,Russia } \\
\text { e-mail: am.vodovozov@gmail.com }\end{array}$ \\
\hline $\begin{array}{l}\text { Для цитирования: } \\
\text { A.M. Vodovozov. } \\
\text { Nonlinear Pulse-Time Conversion in Radioisotope Devices: } \\
\text { Analysis and Application Possibilities. } \\
\text { Приборы и методы измерений. } \\
\text { 2021. - T. 12, № 2. - C. 133-138. } \\
\text { DOI: } 10.21122 / 2220-9506-2021-12-2-133-138\end{array}$ & $\begin{array}{l}\text { For citation: } \\
\text { A.M. Vodovozov. } \\
\text { Nonlinear Pulse-Time Conversion in Radioisotope Devices } \\
\text { Analysis and Application Possibilities. } \\
\text { Devices and Methods of Measurements. } \\
\text { 2021, vol. 12, no. 2, pp. 133-138. } \\
\text { DOI: } 10.21122 / 2220-9506-2021-12-2-133-138\end{array}$ \\
\hline
\end{tabular}




\section{Introduction}

In severe operating conditions, radioisotope measuring devices such as thickness gauges, altimeters, density meters, level gauges, often significantly outperform their competitors, which use different physical principles to solve the problem. Despite the radiation hazard and the complexity of operation, they still remain indispensable in solving numerous problems in the field of non-destructive testing of complex technological processes [1-6].

All radioisotope devices use an indirect measurement method. In them, the desired value of the measured physical parameter is determined based on the transformations of the radiation detector signal associated with the measured physical quantity of the nonlinear calibration curve. The calibration curve in such devices is established experimentally or theoretically based on the results of studies of physical processes in static operating modes. The output variable of the calibration curve is the intensity (average frequency) of the pulse stream formed at the output of the ionizing radiation detector. The latter is considered to be the simplest Poisson flow with the properties of stationarity, ordinariness, and absence of aftereffect.

In the existing practice of constructing radioisotope measuring devices $[1-2,7]$, the measurement process is reduced to assessing the flux intensity $\lambda$ followed by calculating the nonlinear function of the reciprocal calibration curve of the sensor. The estimation of the flow intensity, in turn, is performed by quantizing the process in time and counting the number of fixed pulses $N$ for the selected quantization interval $T$ according to the formula $\lambda=N / T$. The quantization interval $T$ is selected based on the requirements for the value of the statistical error of the meter. In accordance with the assumptions about the Poisson distribution of the information signal, the statistical error of this information processing process is inversely proportional to the duration of the quantization interval. A typical conversion algorithm is valid for slowly changing processes and is completely unsuitable for measurements under dynamic conditions when the measured value changes over time.

In dynamic modes, the operation of a radioisotope measuring device changes significantly, the flow of pulses at the detector output becomes unsteady, and in a typical signal processing process, many contradictions appear, leading to distortion and loss of information in the channel. In this case, it is necessary to consider not the intensity (average frequency) of the random flow, but its instantaneous density as the information parameter of the Poisson flow. The estimate of the flow intensity carries a dynamic error associated with averaging the process over time. Here a conflict arises between the requirements for minimizing the statistical and dynamic errors of the meter, since the dynamic measurement errors always increase with an increase in the quantization interval [8].

If we assume that the time-varying input variable (measurable value) has a limited spectrum, then, according to the KotelnikovShannon sampling theorem [9], it can be absolutely accurately represented by a set of individual values (samples) following at equal intervals, provided that the repetition rate of these samples is at least twice the upper limit of the signal spectrum. Based on this position, it would be possible to choose the quantization interval in the system according to the formula $T \leq 1 / 2 f_{\text {max }}$, where $f_{\max }$ is the maximum frequency in the spectrum of the useful signal.

However, the nonlinear transformation inherent in the calibration curve of the device significantly expands the spectral composition of the information signal towards higher harmonics, the problem of determining the upper limit of the spectrum $f_{\text {max }}$ becomes dependent on the type of nonlinearity and, for this reason, difficult to solve. For these reasons, the requirement to linearize the static characteristics of a radioisotope meter used to estimate the parameters of objects under dynamic conditions can be considered mandatory. The problem of linearizing the characteristics of radioisotope measuring systems is formulated similarly to the same problems in systems of other types - when processing a radiation signal, it is necessary to calculate the conversion function in real time, which is reciprocal to the calibration curve of the meter. The article proposes to solve this problem using the methods of pulse time conversion, which provides fast calculations in real time.

The purpose of the research was the development of algorithms for the nonlinear pulsetime transformation of the Poisson process in the structure of a radioisotope device and the analysis of 
the possibility of its application for linearization of the characteristics of the device.

\section{Pulse-time transformation of the Poisson process}

The maximum operating speed of a radioisotope meter can provide a transition from counting pulses at the output of a radiation detector to measuring time intervals $t$ between pulses, as is done in computing devices that perform timeto-pulse conversions [10]. In such calculators, all conversions are started at the moments when each new pulse appears at the output of the radiation detector and are performed as a function of the measured interval $t$. As a result, with further averaging, calculations in the function of the flux intensity $\lambda$ can be replaced by calculations in the function of the average time interval $\tau=1 / \lambda$.

The time intervals $t$ between the pulses of the Poisson flow are random quantities obeying the exponential distribution law [11]:

$$
p(t)=\lambda \exp (-\lambda t)=\exp (-t / \tau) / \tau,
$$

where $p(t)$ is the probability of occurrence in the stream of pulses of the interval $t ; \lambda$ is the flow rate; $\tau=1 / \lambda$ is the average value (mathematical expectation) of the intervals between pulses.

Pulse-time conversion of a stream implies that the calculation of a given nonlinear function is performed at the moments of occurrence of each event without any signal filtering. In this case, the filtering problem is solved after a nonlinear transformation and is reduced to evaluating the mathematical expectation of the signal at the output of the timepulse converter. The mathematical expectation of the signal at the output of the nonlinear converter $F(\tau)$ can be calculated by the formula:

$$
F(\tau)=\int_{0}^{\infty} p(t) f(t) d t,
$$

where $f(t)$ is a nonlinear function calculated by the time-pulse converter in each interval $t$.

Equations (1) and (2) give a general formula for calculating the conversion function of the pulse-time converter:

$$
F(\tau)=\frac{1}{\tau} \int_{0}^{\infty} f(t) \exp (-t / \tau) d t=\frac{1}{\tau} L\{f(t)\},
$$

where $L\{f(t)\}$ is the Laplace transform of the function $f(t)$.
In this case, the function $f(t)$ acts as the original of the Laplace transform, and the construction of a time-pulse computing device is reduced to the search for the original $f(t)$ according to a given mathematical description of the transformation function $F(\tau)$. For a number of specific functions, this problem can be solved directly using the tables of Laplace transforms [12] using the shift, similarity theorem and damping theorems.

\section{Practical implementation of the algorithm}

Unfortunately, the physical theory of the interaction of radioactive radiation with matter does not provide sufficient solutions that would meet the technological requirements of modern production with an acceptable error. The calibration curve of a radioisotope device, which describes the dependence of the intensity of the pulse flux at the output of the radiation detector on the measured parameter of the material, is associated with complex processes of multiple reflection and absorption of radiation in the substance and, for this reason, is always nonlinear. A common way to describe the transformation function of the information processing in a radioisotope device is its direct experimental calibration, and to select a more or less adequate calculation model of the transformation function $F(\tau)$, the mathematical apparatus for approximating experimental data is used.

Here the most important is the problem of choosing a class of a suitable approximating function that can be implemented by means of a pulsetime conversion takes into account the previously obtained equation (3). Equation (3), which contains the Laplace transform, is valid only for linear and nonlinear functions $f(t)$ satisfying the conditions for the existence of an image: for functions with real and zero poles, integrable on any finite positive interval of the $t$ axis; taking zero values for all negative values of $t$ and increasing no faster than the exponential function. Of the set of functions satisfying these conditions, the most interesting is the power transformation function $F(\tau)=\tau^{n}$, to which the original also corresponds in the form of a power function $f(t)=t^{n} / n !$. Therefore, the solution to the problem can be an approximation of the transformation function of the computing device $F(\tau)$ with a power series:

$F(\tau)=\sum_{n=0}^{K} a_{n} \tau^{n}$ 
where the number of terms of the series $K$ and its coefficients $a_{n}(n=0 \ldots N)$ are determined by the given error and the chosen approximation method.

To implement the transformation according to equation (4), it is necessary to use a time-pulse device, which reproduces the function in the form of a series in each cycle of calculations:

$f(\tau)=\sum_{n=0}^{K} \frac{a_{n}}{n !} t^{n}$.

\section{Linearization of the characteristics of a radioisotope altimeter}

As an example of using the proposed technique, let us consider the problem of linearizing the characteristics of a radioisotope altimeter, for which the dynamic mode of operation is relevant. The calibration curve of the altimeter $\lambda(H)$ is given in [13]. The meter operates in the range of heights $H=0.5 \div 9 \mathrm{~m}$ with changes in the pulse flow intensity in the range $\lambda=500 \div 5000 \mathrm{~Hz}$ (Figure 1).

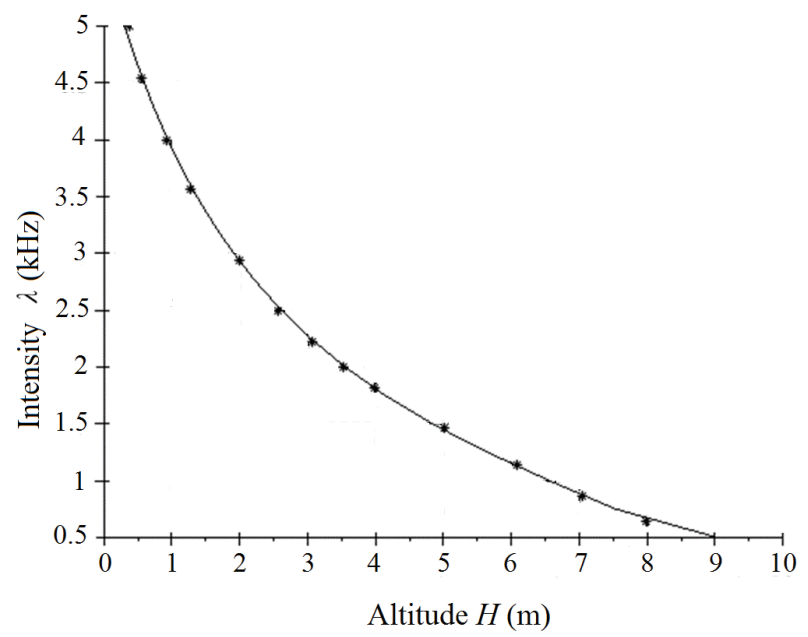

Figure 1 - Calibration curve of a radioisotope altimeter

The transformation function of the computing device $F(\tau)$ in the form of a power series (4) of the third order with coefficients $a_{0}=-2.66, a_{1}=+16.64$, $a_{2}=-9.43, a_{3}=2.02$ calculated on the given dataset using the least squares method and is shown in Figure 2.

The simulation of the pulse-time conversion process was carried out in the Scilab program [14], where a set of random intervals with an exponential distribution was generated, processed according to formula (5) and filtered subsequently. Figure 3 shows the linearized meter response obtained by averaging over 1000 tests.

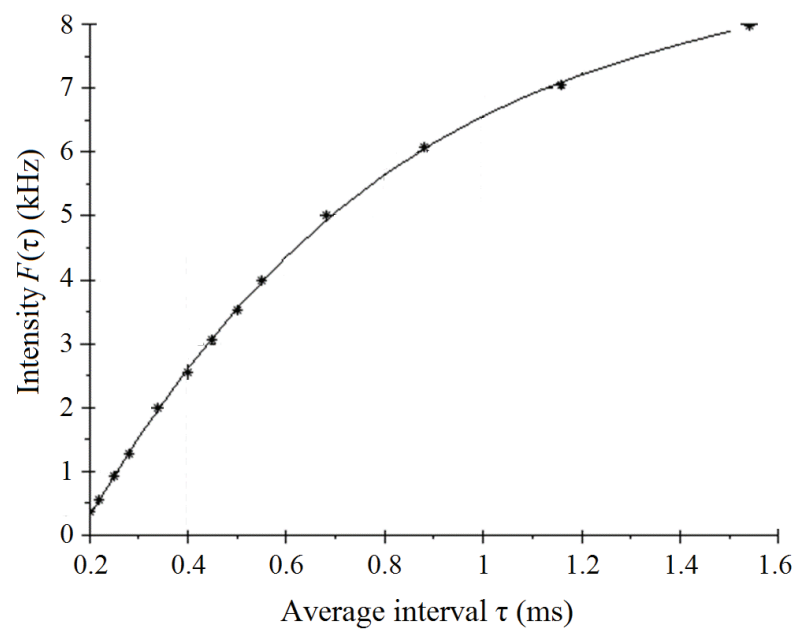

Figure 2 - Pulse-time converter conversion function

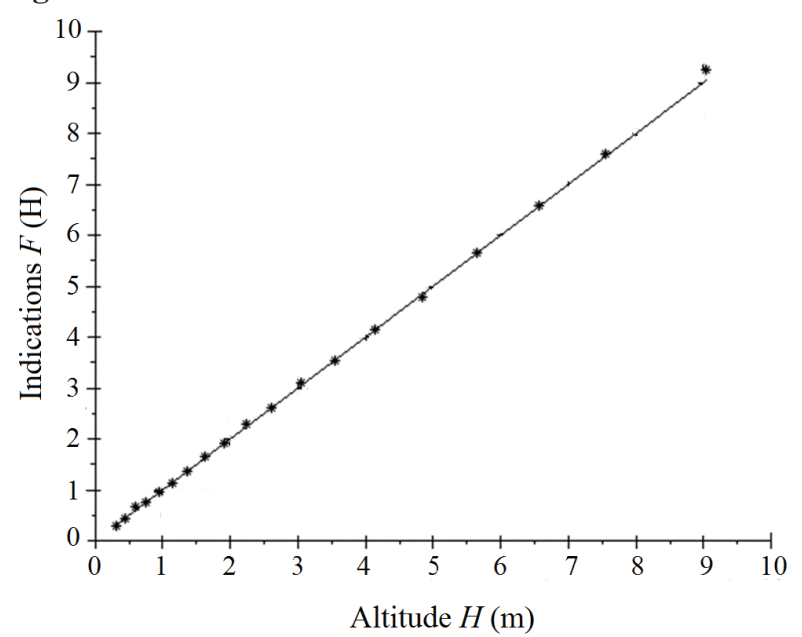

Figure 3 - Linearized altimeter curve

The altimeter curve formed as a result of the research is linear, which proves the validity of the hypothesis about the possibility of using the pulsetime conversion of the radiation signal to linearize the meter curve.

\section{Conclusion}

The results obtained confirm the possibility of using time-pulse functional converters to linearize the conversion curve of radioisotope measuring devices in real time. Carrying out calculations according to the proposed algorithms by means of modern microelectronics opens up new possibilities for expanding the field of application of radioisotope systems towards dynamic measurements in problems of industrial flaw detection, in devices for measuring the height, thickness of rolled products, thickness of coatings, in continuous liquid media monitors, etc. At the same time, the issues of implementing the proposed algorithms by means of microprocessor 
technology and controllers that are part of radioisotope devices and solve the problems of filtering a useful signal become relevant.

\section{References}

1. Basova E.V., Chasovskikh V.P. Ispol'zovanie radioizotopnykh tolshchinomerov dlya opredeleniya tolshchiny pristenochnykh otlozhenii na vnutrennikh stenkakh tsiklona [Use of radio isotope devices for defining the thickness of adjournment on internal walls of the cyclone]. Fundamental'nye issledovaniya [Fundamental research], 2011, no. 12-4, pp. 760-765.

2. Kuzelev N.R., Egolin Ya.G. Datchiki FGUP "VNIITFA» dlya system kontrolya $i$ upravleniya tekhnologicheskimi protsessami [Fsue "VNIITFA" sensors for monitoring and control systems of technological processes]. Voprosy atomnoi nauki itekhniki. Seriya: Tekhnicheskaya fizika i avtomatizatsiya [Questions of atomic science and technology. Series: Technical Physicsand Automation], Moscow, Nauchno-issledovatel'skii institute tekhnicheskoi fiziki i avtomatizatsii Publ., 2005, pp. 6-11 (in Russian).

3. Bochenin V.I. Radioisotope method for monitoring the level of wear for protective coatings made from chromium and aluminum on gas turbine blades. Measurement Techniques, 2006, vol. 49, no. 10, pp. 10071010. DOI: $10.1007 / \mathrm{s} 11018-006-0227-0$

4. Beigzadeh A., Vaziri R., Afaride H. Measurement of temperature dependence of water density using the tool designed gamma densitometer. Iranian Journal of Physics Research, 2019, vol. 19, no. 3, pp. 529-535.

5. Yermakovich O.L., Lisovskiy G.A., Kuchinskiy P.V., Titovitskiy I.A. Povysheniye tochnosti izmereniy radioizotopnogo plotnomera [Increasing the accuracy of radio isotope measurements density]. Pribory $i$ metody izmerenii [Devices and Methods of Measurements], 2015, vol. 1, no. 10, pp. 70-75 (in Russian).

6. Vodovozov A.M. Linearization of the static characteristics of a radioisotope density meter. Measurement Techniques, 2018, vol. 61, pp. 950-954.

DOI: $10.1007 / \mathrm{s} 11018-018-1531-1$
7. Vodovozov A.M. Digital processing of measurement information in radioisotope devices. Measurement Techniques, 2018, vol. 61, pp. 177-181.

DOI: $10.1007 / \mathrm{s} 11018-018-1406-5$

8. Sobolev V.I. On the correspondence between dynamic and static errors in data measurement systems. Measurement Techniques, 2014, vol. 57, pp. 247-254.

DOI: $10.1007 / \mathrm{S} 11018-014-0440-1$

9. Troshchenkov A.I. Teorema Kotel'nikova-Shennona i prakticheskoye ispol'zovaniye tselykh funktsiy dlya predstavleniya signala na priyemnoy storone [KotelnikovShannon theorem and practical use of entire functions for signal representation on the receiving side]. Raketnokosmicheskoye priborostroyeniye $i$ informatsionnyye sistemy [Rocket and Space Instrument Engineering and Information Systems], 2018, vol. 5, iss. 1, pp. 81-85.

DOI: $10.30894 /$ issn2409-0239.2018.5.1.81.85

10. Vodovozov A.M. Nonlinear real-time problems in stochastic system with Poisson component. Journal of Instrument Engineering, 2020, vol. 63, no. 6, pp. 501-506 (in Russian).

11. Kingman D. Poisson Processes. Moscow, MTsNMO, 2007.

12. Shynk J.J. Mathematical Foundations for Linear Circuits and Systems in Engineering. Santa Barbara, University of California, 2016.

13. Malykhina G.F., Kislitsyna I.A. Izmerenie parametrov dvizheniya s ispol'zovaniem neironnykh setei [Measurement of motion parameters using neural networks]. Nauchno-tekhnicheskie vedomosti SanktPeterburgskogo gosudarstvennogo politekhnicheskogo universiteta. Informatika. Telekommunikatsii. Upravlenie [Scientific and technical bulletins of the St. Petersburg State Polytechnic University. Informatics. Telecommunications. Control], 2015, no. 5 (229), pp. 59-68.

DOI: $10.5862 /$ JCSTCS. 229.6

14. Alekseev E.R., Chesnokova O.V., Rudchenko E.A. Scilab: Reshenie inzhenernykh $i$ matematicheskikh zadach [Scilab: Solution of engineering and mathematical problems], Moscow, ALTLinux; BINOM. Laboratoriya znanii, 2008. 